\title{
EXPERIMENTAL BRIDGING OF OSSEOUS DEFECTS IN RATS BY THE IMPLANTATION OF KIEL BONE CONTAINING FRESH AUTOLOGOUS MARROW
}

\author{
Hanns Plenk, Jun., Karl Hollmann and Karl-Heinz Wilfert, Vienna, Austria \\ From the Institute of Histology and Embryology, and the Clinic for Maxillo-facial Surgery, \\ University of Vienna
}

\begin{abstract}
Autologous bone grafts are generally considered the most suitable transplants for an osseous defect. Viable cells with osteogenic capacity within the bone marrow, the periosteum and the bone itself may survive transplantation and form new bone (Axhausen 1964, Burwell 1964, $1966 a$, Hjørting-Hansen 1970). Bone obtained from organ banks and also the so-called Kiel bone have lost this osteogenic capacity because of preserving and denaturing procedures: they can induce bone formation only at sites where cells with the capacity to form bone are present. Hitherto the implantation of such bone grafts into osseous defects or into a bed of connective or muscular tissue has not been successful (Heiple, Chase and Herndon 1963; Axhausen 1964; Schweiberer and Axhausen 1965).

It has been repeatedly stated that autologous red bone marrow can stimulate the formation of bone (Chiari 1912; Burwell 1964; Richter, Sugg and Boyne 1968; Boyne and Yeager 1969). Moreover, this osteogenic capacity of fresh autologous marrow can be transferred not only to marrow-free autologous and homologous bone grafts (Burwell 1964), but also to various types of stored bone (Burwell 1966a). A composite graft of bone and marrow forms considerably more new bone than do either of the components of the graft transplanted separately (Burwell 1964).

The aim of this study was to investigate whether osteogenic capacity could be imparted to Kiel bone by supplementation with fresh autologous marrow and whether such a composite graft could bridge an osseous defect.
\end{abstract}

\section{MATERIALS AND METHODS}

Fifty-one male and female Wistar rats weighing 220 to 330 grammes were used for the investigation.

Operative procedures- - Under ether anaesthesia a piece of bone together with the periosteum was excised either from the right ischium or in a few cases from the ilium, thus creating a gap of about 5 millimetres; subperiosteal resection was carefully avoided. Pieces of sterile packed, cancellous Kiel bone were exactly adapted to the length of the excised pieces of bone (Fig. 1). The width and height of the grafts, however, were twice those of the excised bone pieces. Before implantation the Kiel bone grafts were modified in one of the following ways. Composite grafts of Kiel bone and fresh autologous marrow - In each of twenty-eight animals the marrow cavity of the left femur was punctured from the knee joint and 0.1 to 0.3 millilitres of red marrow was aspirated in a syringe. To prevent coagulation 0.1 millilitre of heparin solution ( 500 units per millilitre) had previously been drawn into the syringe. The Kiel bone was impregnated with the aspirated marrow by lightly massaging it into the spongy bone; this composite graft was then inserted into the osseous defect of the rat from which the marrow was obtained. Each marrow extract was controlled by a smear. The effectiveness of the impregnation was assessed by histological examination of random samples. This showed that gentle massage provided a deep penetration of the marrow into the graft. The trabeculae 
and larger Haversian canals were coated by a layer of bone marrow cells, whereas the plasma fluid penetrated as far as the lacunae of the osteocytes.

Unimpregnated Kiel bone grafts-Kiel bone grafts without any impregnation were implanted in ten rats.

Kiel bone grafts impregnated with a solution of antibiotics-The Kiel bone grafts were impregnated with a solution of Neomycin and Bacitracin* and inserted into six animals.

Kiel bone grafts impregnated with heparin-The Kiel bone grafts were implanted into four animals after impregnation with a heparin solution (500 units per millilitre).

Controls-In three animals no graft was implanted into the osseous defect.

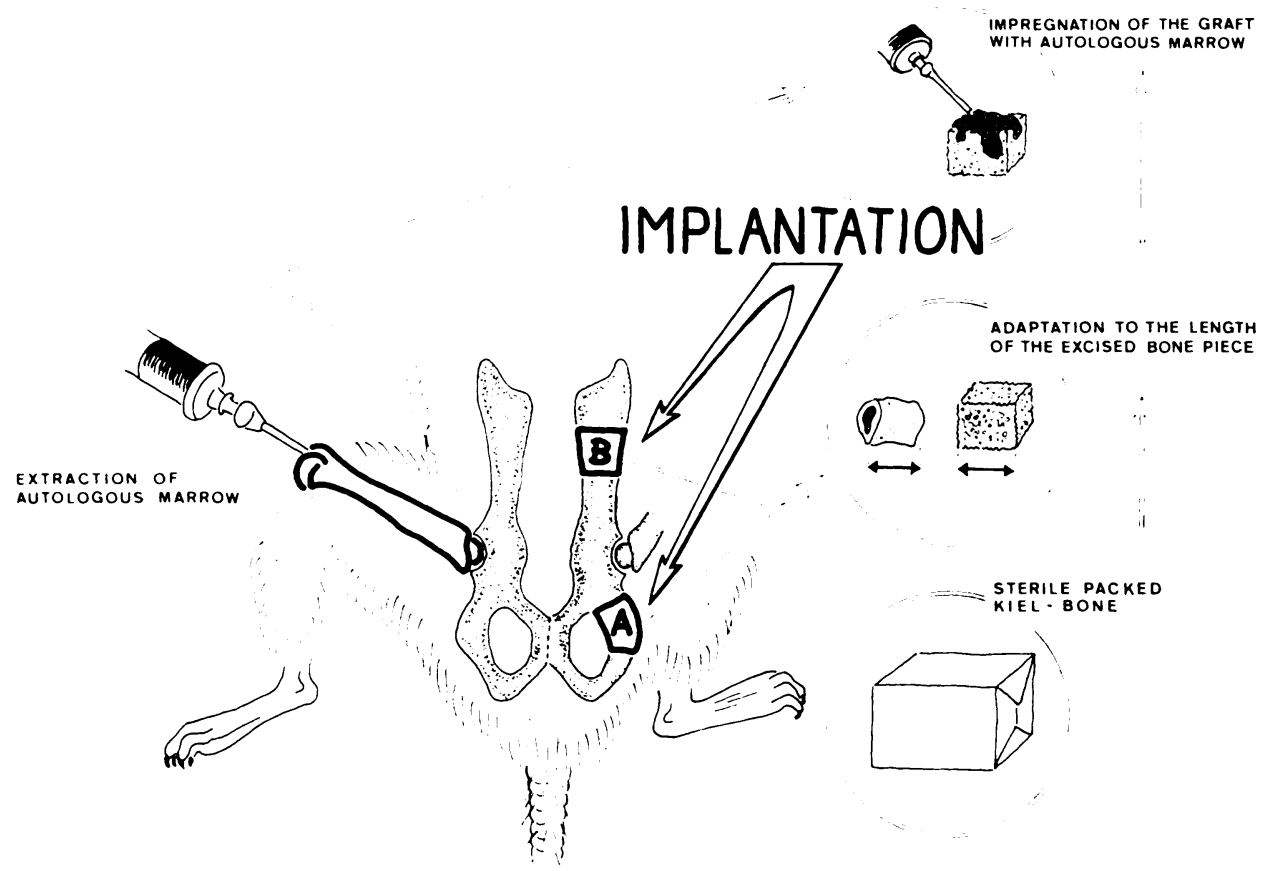

Fig. 1

The method of preparation of the marrow-impregnated Kiel bone graft and the sites of implantation in the ischium (A) and the ilium (B) of the rat.

The muscle layers were closed over the implant and the skin was closed with braided synthetic material. No additional antibiotic protection was given. The animals were kept in individual cages and fed a standard diet of rat pellets and water.

Histological techniques and assessment of new bone formation-The animals were killed twelve, twenty-one, twenty-eight, forty-two, forty-nine, eighty-four, 106 and 135 days after the implantation of the graft. The right half of the pelvis with the graft area was excised, fixed in 5 per cent neutral buffered formaldehyde solution, decalcified in 5 per cent nitric acid or ethylene-diamine-tetra-acetate and embedded in celloidin or celloidin-paraffin wax. The specimens were cut serially at 10 to $20 \mu \mathrm{m}$ thickness so as to include both bony resection stumps of the pelvis and the implanted graft. Each twentieth section was stained with haematoxylin and eosin or Pasini's connective tissue stain (Romeis 1968). The formation of new bone in the implant area and within the graft was examined and the findings subjected to statistical analysis. Rats showing signs of inflammation in the implant area or found dead before the planned time of killing were discarded from the series.

*Nebacetin ${ }^{R}$ for instillation, Lundbeck, Copenhagen. 


\section{RESULTS}

In all animals examined formation of cartilaginous callus and of new bone occurred at the resection stumps of the pelvis.

No graft implanted into the osseous defect-The gap was filled with granulation tissue and organised blood-clots after twenty-eight days and the opened marrow cavities of the resection stumps were found to be closed by newly formed bone. By 135 days fibrous connective tissue had developed in the gap with remaining groups of lymphoid and plasma cells, but no signs of bony repair of the defect were seen.

Composite grafts of Kiel bone and fresh autologous marrow-After twelve days the implant area and the cavities between the trabeculae of the graft, which was strongly basophilic to haematoxylin-eosin, were filled by vascularised connective tissue rich in cells. Most of these

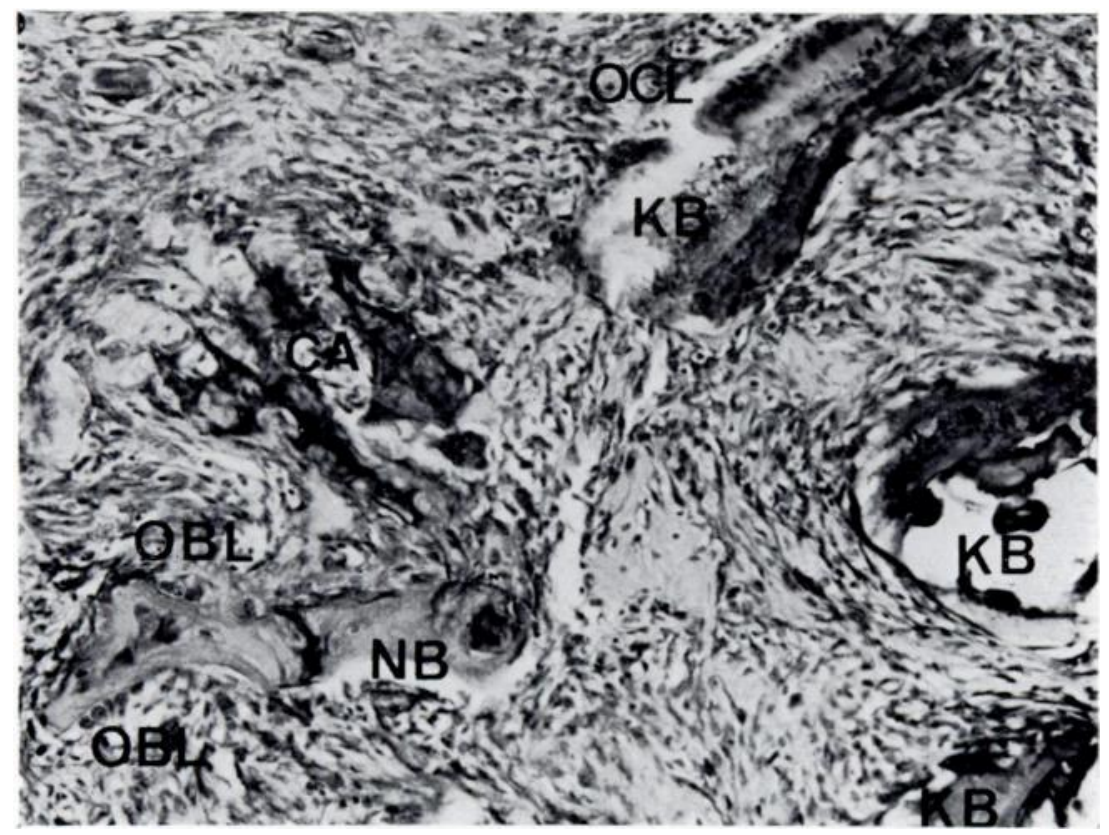

Fig. 2

Marrow-impregnated Kiel bone graft twelve days after implantation. The trabeculae of the grafted Kiel bone (KB) are embedded in cellular tissue. Occasionally osteoclasts $(\mathrm{OCL})$ are found upon their surface. Note the newly formed bone (NB) with osteoblasts $(\mathrm{OBL})$ and the cartilaginous callus (CA). (Haematoxylin and eosin, $\times 160$.)

cells were spindle-shaped and had pale nuclei with one or two nucleoli. Also groups of cells with dark, pyknotic nuclei and eosinophilic granulocytes or groups of cells containing fat vacuoles could be observed. Upon the surface of the grafted bone trabeculae some osteoclasts and multinucleated giant cells could be detected. Occasionally cartilaginous callus and newly formed bone bordered by osteoblasts were found between the trabeculae of the graft (Fig. 2). By twenty-eight days in four of seven animals, and by forty-eight days after implantation in all three animals examined, new bone formation was seen. In one case this had produced bony bridging of the defect. The trabeculae of the graft were mostly covered by newly formed bone with osteoblastic activity on its surfaces, but some cartilaginous callus was still present (Fig. 3). At the borders of the graft, however, the trabeculae were embedded in fibrous connective tissue showing osteoclastic resorption. The cavities within the new bone were filled by haemopoietic marrow and fat cells (Fig. 4).

VOL. 54 B, NO. 4, NOVEMBER 1972 


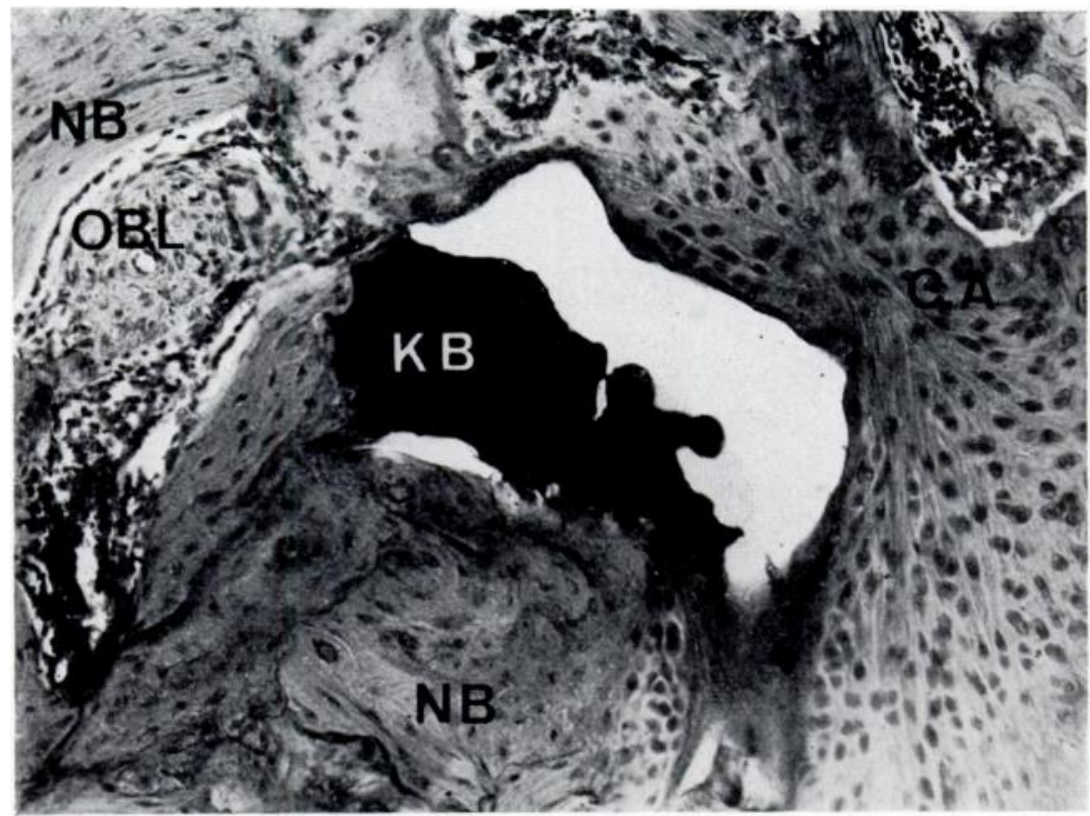

FIG. 3

Marrow-impregnated Kiel bone graft forty-two days after implantation. The grafted Kiel bone (KB) is embedded into new woven bone (NB), showing osteoblastic activity $(\mathrm{OBL})$. Cartilaginous callus (CA) is still present. (Haematoxylin and eosin, $\times 140$.)

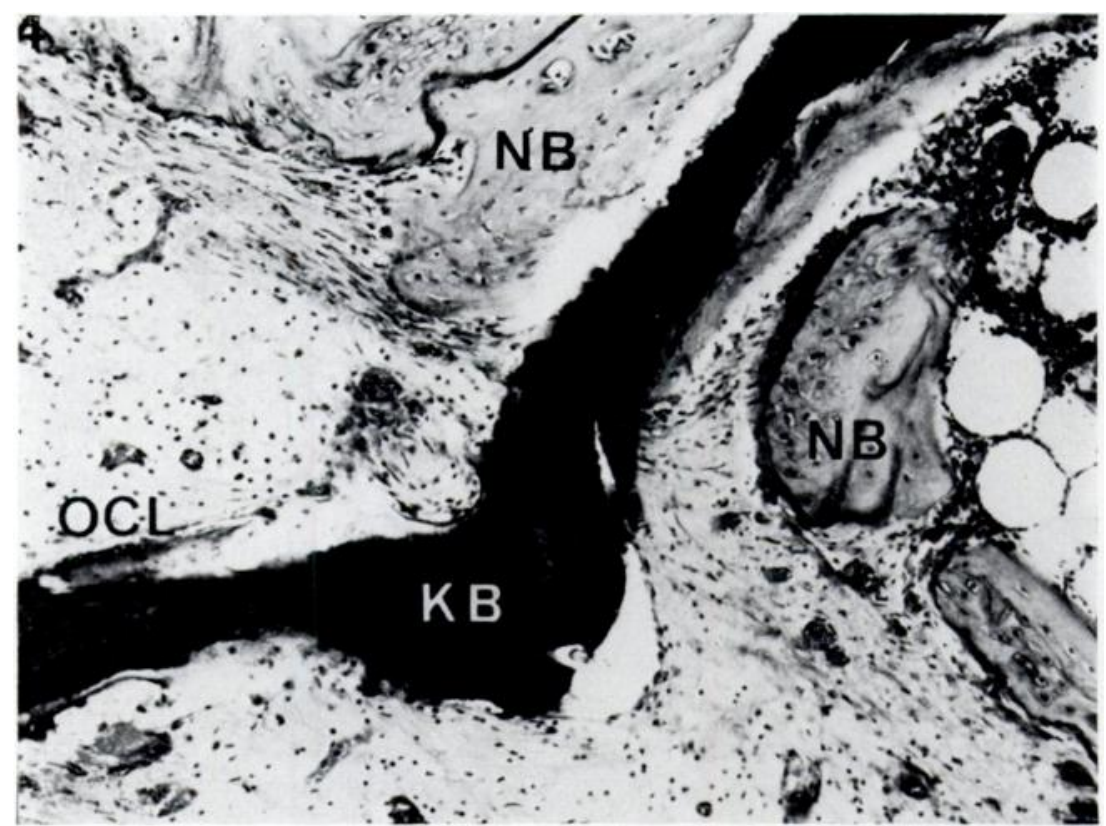

FIG. 4

Marrow-impregnated Kiel bone graft forty-nine days after implantation. At the borders of the graft the trabeculae of Kiel bone (KB) are embedded partly into new bone (NB), partly into fibrous connective tissue. Note the multinucleated osteoclast (OCL). (Haematoxylin and eosin, $\times 140$.) 


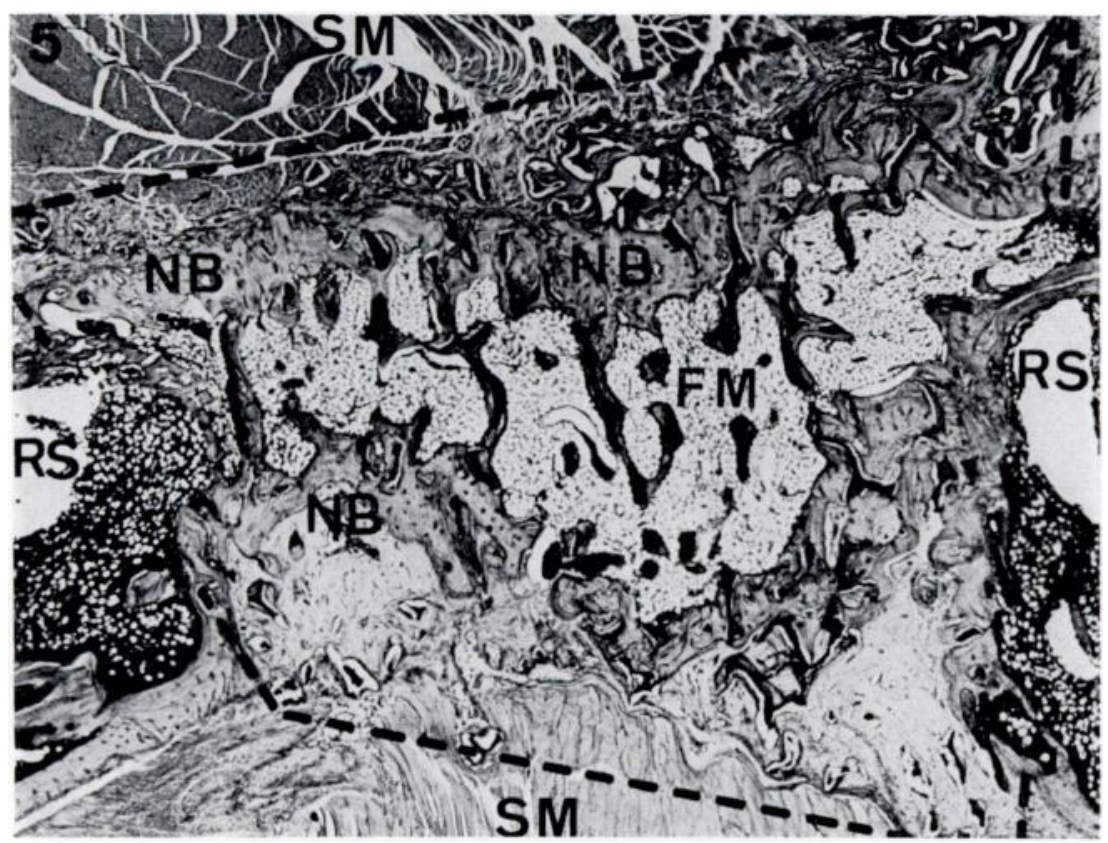

Fig. 5

The implant area with a marrow-impregnated Kiel bone graft 135 days after implantation. The Kiel bone graft (dotted line) is embedded for the most part into new bone (NB) which forms a continuous bony bridge between both resection stumps (RS) of the ischium. The marrow cavities of the bridge are filled with fatty marrow (FM). SM $=$ skeletal muscle fibres. (Haematoxylin and eosin, $\times 11$.)

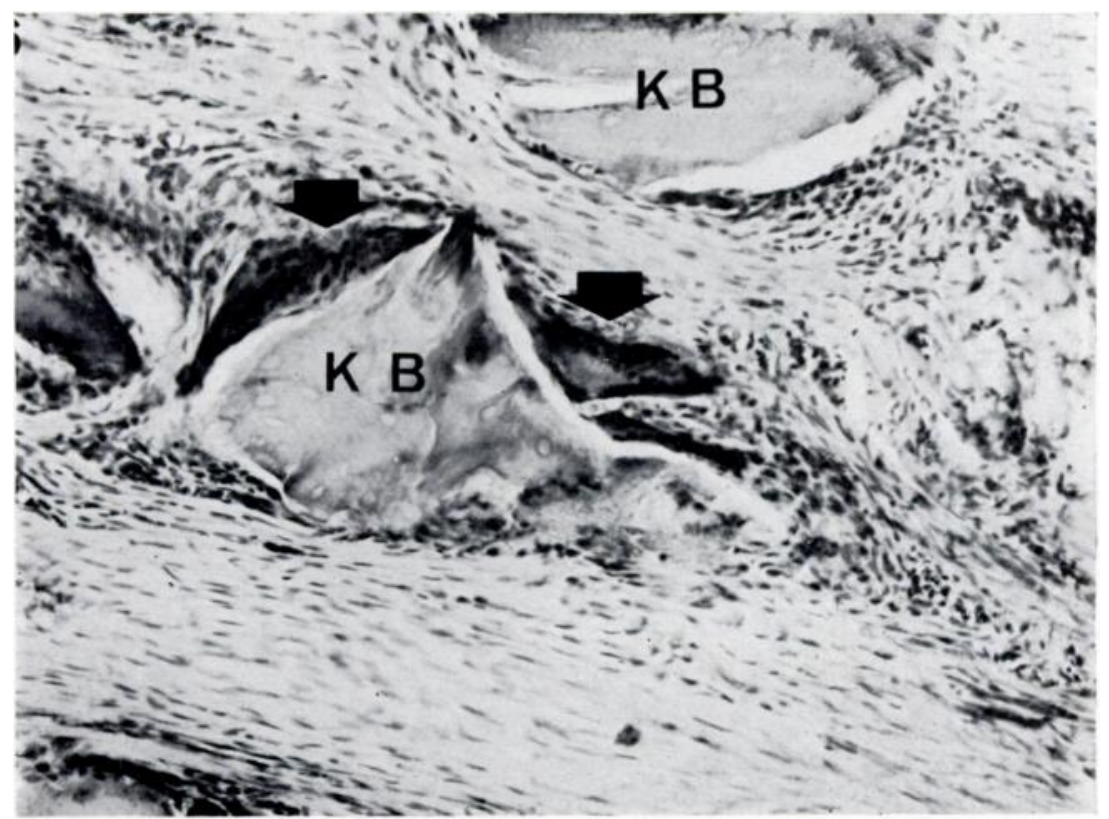

Fig. 6

Unimpregnated Kiel bone graft twenty-eight days after implantation. The trabeculae of the grafted Kiel bone $(\mathrm{KB})$ are surrounded by small round cells and multinucleated giant cells (arrows). (Haematoxylin and eosin, $\times 160$.) 
By 135 days after implantation in six of nine animals new bone formation could be seen within the implant area and in three of these a continuous bony bridge developed over the defect. Almost the whole grafted bone was embedded in lamellar bone, so that the diameter of the bridge was often twice as wide as that of the resection stumps. The marrow cavities of the bridge were filled with fatty marrow (Fig. 5).

In those cases in which no bone formation could be observed in the implant area, the trabeculae of the graft were found to be surrounded by a dense layer of little round cells and

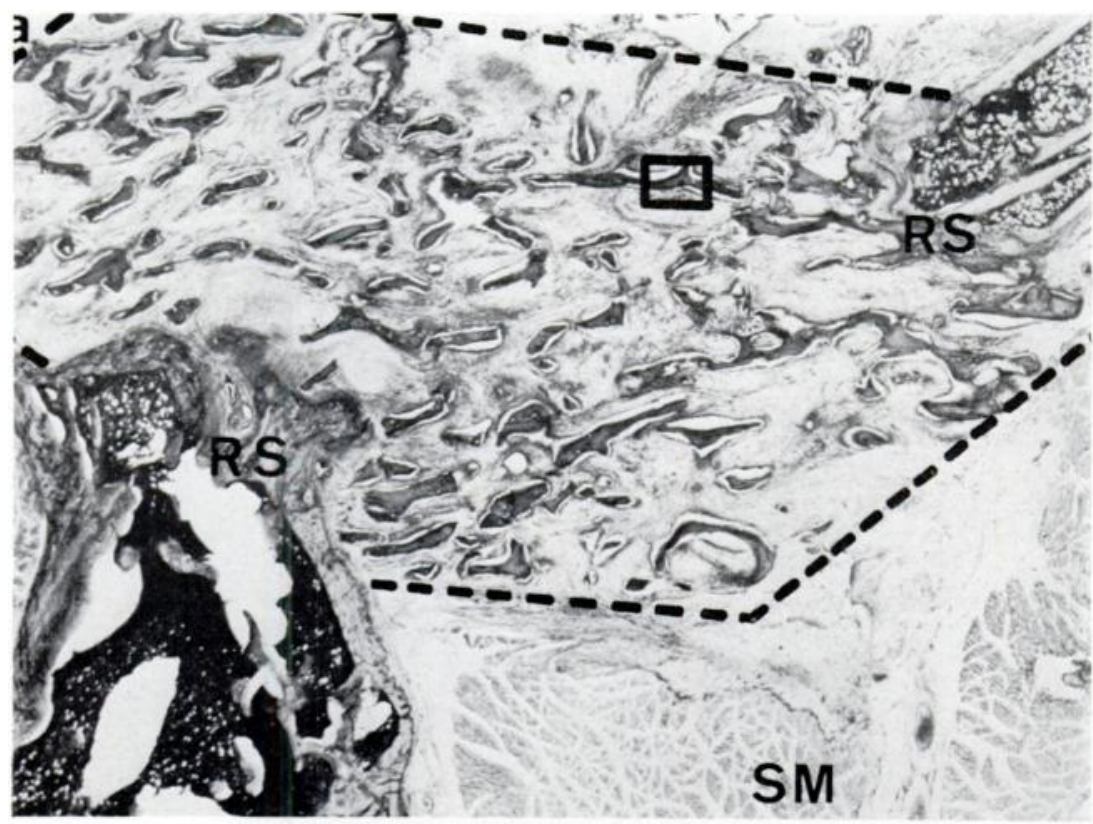

FIG. 7

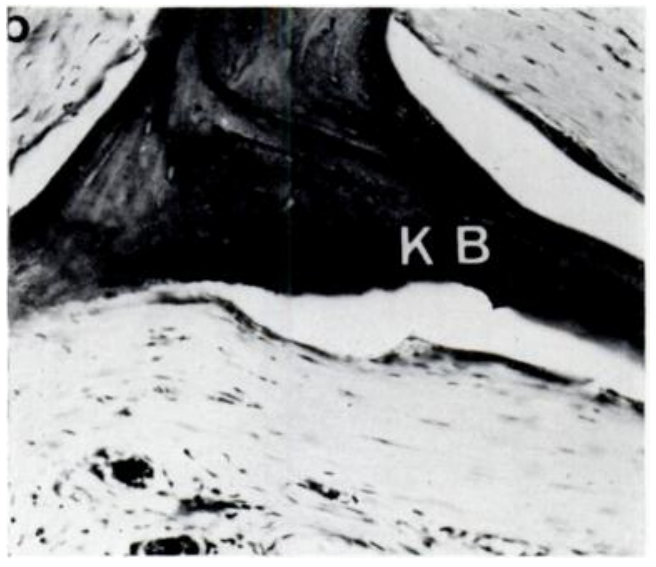

Figs. 7 AND 8

Unimpregnated Kiel bone graft 106 days after implantation. Figure 7-Nowhere within the Kiel bone graft (dotted line) can new bone formation be seen. $\mathbf{R S}=$ resection stumps of the ischium; $\mathbf{S M}=$ skeletal muscle fibres. (Haematoxylin and eosin, $\times 11$.) Figure 8-High magnification of the area within the rectangle in Figure 7 . The trabeculae of the grafted Kiel bone (KB) are encapsulated by fibrous connective tissue showing no cellular reaction. (Haematoxylin and eosin, $x$

Fig. 8

some multinucleated giant cells. Fibrous connective tissue, containing groups of lymphoid and plasma cells as well as vascular sinusoids, filled the spaces between the trabeculae. In one case the graft had emigrated from its site of implantation and was found penetrating through the skin of the animal without considerable inflammatory reaction. The absence of bone formation and also of inflammatory reaction seemed to occur more frequently in those animals in which the amount of marrow obtainable was relatively small. 
Unimpregnated Kiel bone grafts-By twenty-eight days these were embedded in connective tissue, which formed a cellular layer with multinucleated cells around the trabeculae of the graft, whereas the spaces between them appeared rather fibrous (Fig. 6). Nowhere in the implant area could bone formation be seen. By 135 days after the implantation the grafts were found to be encapsulated by fibrous connective tissue, showing little or no cellular reaction around the trabeculae (Figs. 7 and 8 ). Formation of bone was seen in only one case, in which a small amount of new bone, arising from the proximal resection stump of the pelvis and containing fatty marrow, had developed.

Kiel bone grafts impregnated with a solution of antibiotics-In none of the animals of this group was new bone found in the implant area until 135 days after implantation. The changes occurring in these grafts were similar to those described in unimpregnated grafts. The trabeculae of the grafts were not even enclosed by the bone, which was formed at the resection stumps. In these animals no signs of inflammation were observed.

Kiel bone grafts impregnated with heparin-solution-Three of the four animals in this group had to be discarded because of inflammation. In the last rat a small piece of bone was found in the middle of the graft, but, as judged on the serial sections, the rest of the graft was encapsulated by fibrous connective tissue.

The findings are summarised in Table I.

TABLE I

Incidence of Bone Formation/No Bone Formation in the Different Types of Kiel BONE GRAFTS

\begin{tabular}{|c|c|c|c|c|}
\hline \multirow{2}{*}{ Type of graft } & \multicolumn{3}{|c|}{ Interval between graft and examination (days) } & \multirow{2}{*}{ Total } \\
\hline & $12-28$ & $42-49$ & 84-135 & \\
\hline $\begin{array}{l}\text { Kiel bone impregnated with } \\
\text { autologous marrow }\end{array}$ & $4 / 3$ & $\begin{array}{c}3 / 0 \\
(1 \text { bridge })\end{array}$ & $\begin{array}{c}6 / 3 \\
(3 \text { bridges })\end{array}$ & $\begin{array}{c}13 / 6 \\
\text { (4 bridges) }\end{array}$ \\
\hline Unimpregnated Kiel bone. & $0 / 2$ & $0 / 2$ & $1 / 2$ & $1 / 6$ \\
\hline $\begin{array}{l}\text { Kiel bone impregnated with } \\
\text { a solution of antibiotics }\end{array}$ & $0 / 1$ & $0 / 2$ & $0 / 3$ & $0 / 6$ \\
\hline
\end{tabular}

The lower number of rats in the groups in which unimpregnated and antibioticimpregnated grafts were implanted and which served as controls, required a statistical analysis of the results. It seemed to be justified to pool the results of both groups, because the number of cases within the three observation periods was approximately comparable with the number of cases in which a marrow-impregnated Kiel bone graft has been implanted. According to the hypergeometric distribution the probability for these results to occur by chance is less than 0,002 .

\section{DISCUSSION}

It is seen from Table I that in the marrow-impregnated Kiel bone grafts strikingly more new bone was formed than in the unimpregnated and the antibiotic-treated grafts. The two latter methods are those by which a Kiel bone graft is usually applied (Maatz and Bauermeister 1961, Lahninger and Salem 1964). In these controls the Kiel bone induced almost no bone formation and was simply encapsulated by connective tissue. The statistical analysis confirmed these findings, and it may therefore be concluded that a Kiel bone graft supplemented with fresh autologous marrow is superior to the control methods with regard to bone formation.

As pointed out by Burwell $(1966 a, b)$, the lack of osteogenic potency in preserved bone may be corrected either "by natural invasion of the implant by bone-forming cells at the site

VOL. 54 B, NO. 4, NOVEMBER 1972 
of implantation" or "by artificial impregnation of the implant with bone-forming cells before implantation".

The first of these possibilities is in agreement with the term "ersatzstarkes Lager" (osteogenic potent site) coined by Lexer (1934). The formation of new bone proceeding from the proximal resection stump of the ischium, which we observed after the implantation of an unimpregnated Kiel bone graft, may be due to this mechanism. The amount of the induced, newly formed bone does not seem to be sufficient to bridge a large osseous defect. Although implantation into an osseous defect, especially in the pelvis, may not be a reliable method for testing the induction of osteogenic potency in a graft (Hjørting-Hansen 1970), we chose this site of implantation because up to now Kiel bone grafts have not succeeded in bridging an osseous continuity defect for instance, in the jaws (Hollmann 1970).

In accordance with the second possibility we impregnated Kiel bone grafts with fresh autologous marrow before implantation. The results showed that formation of new bone occurred not only in most of these composite grafts, but also that a continuous bony bridge over the osseous defect developed in four of thirteen cases.

Similar results with composite grafts were obtained by other investigators (Matthes, Gibel, Wildner and Marx 1968), using homologous bone grafts, which were prepared in a similar way as Kiel bone and were combined with autologous marrow and spongiosa. The commercially available "Kieler-Knochenspan" (Braun-Melsungen, Germany) seems preferable because it can be stored sterile and is ready for use in all quantities and sizes. In our opinion this sort of preserved bone may be superior to the "deproteinised" bone tested by Burwell (1966a) because of its better mechanical qualities (Böttger 1966) and its probable inductive capacity for callus and bone formation (Maatz and Bauermeister 1961; Fuchs, Stegemann and Eger 1963; Schweiberer, Hofmeier and Müller 1967), which is probably due to the incomplete extraction of proteins during preparation. Nevertheless Kiel bone does not seem to induce an immune reaction (Kienholz and Kemkes 1956). Pure, fresh autologous bone marrow is also preferable because it is easier to obtain in sufficient quantity than marrow and spongiosa or marrowcontaining autologous bone grafts, particularly in humans. Moreover, spongiosa fragments within bone marrow transplants do not seem to induce appreciable bone formation (Burwell 1964).

The rather small amount of bone marrow obtainable from the femora may have caused the few failures in our experiments. A relationship seems to exist between the amount of marrow used for the impregnation of the graft and the bone formation induced (Friedenstein, Piatetzky and Petrakova 1969). Furthermore, the frequent occurrence of inflammation around the heparin-impregnated grafts suggests an inflammatory effect of the relatively high concentration of heparin which was used with the bone marrow extract. However, this inflammatory reaction could be caused by the lack of antibiotic protection (Grasser 1970) in these cases.

Impregnation with fresh autologous bone marrow may induce osteogenic potency in Kiel bone, so that a better substitute for autologous bone is produced. The composite Kiel bone graft should not only produce better results in sites where Kiel bone grafts have been used successfully, but also in sites where up to now they have given disappointing results.

\section{SUMMARY}

1. Into osseous defects cut in the pelvis of rats, Kiel bone grafts were implanted after impregnation with the animals' own fresh bone marrow, obtained by femoral puncture. Unimpregnated Kiel bone grafts and Kiel bone grafts impregnated with an antibiotic solution were implanted as controls.

2. Histological examination of the implant area showed that in the marrow-impregnated grafts new bone formation could be observed after twelve days, and that during an observation 
period of 135 days after implantation bone formation occurred in thirteen out of nineteen rats. In four of these cases a continuous bony bridge developed over the defect.

3. In the unimpregnated grafts no more than a small amount of new bone was seen in only one of seven rats. In the antibiotic-impregnated grafts no bone formation was found in six rats during the same period of observation.

\section{REFERENCES}

Axhausen, W. (1964): Die Individual- und Artspezifität des transplantierten Knochengewebes. Langenbecks Archiv für klinische Chirurgie vereinigt mit Deutsche Zeitschrift für Chirurgie, 306, 18.

BöTTGER, G. (1966): Ersatz von Femurschaftaneilen durch homologe Knochentransplantate: Tierexperimentelle Untersuchungen. Langenbecks Archiv für klinische Chirurgie vereinigt mit Deutsche Zeitschrift für Chirurgie, 316, 531.

Boyne, P. J., and Yeager, J. E. (1969): An Evaluation of the Osteogenic Potential of Frozen Marrow. Oral Surgery, Oral Medicine and Oral Pathology, 28, 764.

Burwell, R. G. (1964): Studies in the Transplantation of Bone. VII. The Fresh Composite HomograftAutograft of Cancellous Bone: an Analysis of Factors Leading to Osteogenesis in Marrow Transplants and in Marrow-containing Bone Grafts. Journal of Bone and Joint Surgery, 46-B, 110.

Burwell, R. G. (1966a): Studies in the Transplantation of Bone. VIII. Treated Composite HomograftAutografts of Cancellous Bone: an Analysis of Inductive Mechanisms in Bone Transplantation. Journal of Bone and Joint Surgery, 48-B, 532.

Burwell, R. G. (1966b): Biological Problems of Bone Homotransplantation. Dixième Congrès international de Chirurgie orthopédique et de Traumatologie, Paris, Septembre 4-9, p. 585. Bruxelles: Les Publications "Acta medica Belgica".

CHIARI, O. M. (1912): Vorläufige Mitteilung über Knochenmarkstransplantation. Münchener Medizinische Wochenschrift, 59, 2502.

Friedenstein, A. J., Piatetzky, I. I., and Petrakova, K. V. (1969): Osteogenesis in Transplants of Marrow Cells. Arkhiv anatomii, gistologii i embriologii, 56, 3.

Fuchs, G., Stegemann, H., and Eger, W. (1963): Der transplantierte Knochen und seine Qualität nach partieller und vollständiger Enteiweissung bei erhaltener anorganischer Substanz. Langenbecks Archiv für klinische Chirurgie vereinigt mit Deutsche Zeitschrift für Chirurgie, 303, 240.

Grasser, H.-H. (1970): Die Behandlung von Kieferfrakturen mit Kunststoff und Fremdknochen. Edited by H.-H. Grasser. München: C. Hanser.

Heiple, K. G., Chase, S. W., and Herndon, C. H. (1963): A Comparative Study of the Healing Process Following Different Types of Bone Transplantation. Journal of Bone and Joint Surgery, 45-A, 1593.

Hugrting-Hansen, E. (1970): Studies on Implantation of Anorganic Bone in Cystic Jaw Lesions. Copenhagen: Munksgaard.

Hollmann, K. (1970): Der Kieler Knochenspan in der Kieferchirurgie. Wiener klinische Wochenschrift, 82, 397.

KIENHOLZ, M., and KeMKES, B. (1956): Untersuchungen über den immunbiologischen Wert heteroplastischer konservierter Knochenspäne. Archiv für orthopadische Unfallchirurgie, 48, 623.

Lahninger, J., and Salem, G. (1964): Erfahrungen mit dem Kieler Knochenspan. Chirurg, 35, 495.

LEXER, E. (1934): Vorgänge bei der Knochenverpflanzung. In Lehrbuch der allgemeinen Chirurgie zum Gebrauche fïr Aerzte und Studierende I, pp. 52-57. Edited by E. Lexer. Stuttgart: F. Enke.

MaATZ, R., and Bauermeister, A. (1961): Wesen und Anwendung des Kieler-Knochenspanes. Mitteilungen Braun-Melsungen, 97, 1.

Mattes, Th., Gibel, W., Wildner, G., and Marx, G. (1968): Experimentelle Untersuchungen zur Möglichkeit einer Rekonstruktion der Thoraxwand mit homologen Rippen nach dem Prinzip des Kieler Knochenspanes bei gleichzeitiger Verwendung autologen Knochenmarks und körpereigener Spongiosa. Zeitschrift für Experimentelle Chirurgie und chirurgische Forschung, 1, 360.

Richter, H. E., Jun., SugG, W. E., Jun., and Boyne, P. J. (1968): Stimulation of Osteogenesis in the Dog Mandible by Autogenous Bone Marrow Transplants. Oral Surgery, Oral Medicine and Oral Pathology, 26, 396.

Romeıs, B. (1968): Mikroskopische Technik. Edited by B. Romeis. München: R. Oldenbourg.

Schweiberer, L., and Axhausen, W. (1965): Zur Frage der osteogenetischen Potenz des "Kieler Knochenspans". Langenbecks Archiv für klinische Chirurgie vereinigt mit Deutsche Zeitschrift für Chirurgie, 313, 959.

SChWeiberer, L., Hofmeier, G., and Müller, I. (1967): Ist der macerierte, heterologe Knochenspan (Kieler Knochenspan) ein Calluslocker? Langenbecks Archiv für klinische Chirurgie vereinigt mit Deutsche Zeitschrift für Chirurgie, 319, 450.

Vol. 54 B, NO. 4, NOVEMBER 1972 